\title{
BROKERING IMAGES AND TEXT: AN INTER- VIEW WITH GEOFFREY O'CONNOR
}

Kathryn E. Zichelle

Geoffrey O'Connor came to the University of Iowa on October 17, 1997, for a screening of his new film, Amazon Journal (1996), and for a reading from his accompanying book, Amazon Journal: Dispatches from a Vanishing Frontier (1997). ' His visit was part of a promotional tour sponsored by Amnesty International. O'Connor worked as a journalist and a documentarian in the Amazon during the 1980s and 1990s, prior to, during, and after the period of intense international media attention upon the struggles of indigenous peoples intertwined with the fate of the rain forest. In the film and the book, O'Connor looks critically at the role of the media in presenting these stories to the American public. His previous work includes the films At the Edge of Conquest: The Journey of Chief Wai-Wai (1993), Defying Death in Brazil (1992), and Contact: The Yanomami Indians of Brazil (1990). He also worked as a cameraman for CBS and 60 Minutes, and collaborated with Michael Moore on the television series TV Nation.

Do you see yourself primarily as a filmmaker, as a reporter, as an anthropologist, as a human rights advocate or something else?

I definitely do not see myself as an anthropologist. I describe what I do as ethnographic television, which is a classification that I created myself. I am not an ethnographic filmmaker.

What is the difference between what you are doing and ethnographic films?

The films I make are somewhere between ethnographic films and traditional documentaries. When I say traditional documentaries, I mean the documentary genre as it exists with bits of cinéma vérité. Amazon Journal is part of another tradition of subjective, self-reflective, personal, more subjective storytelling. That genre of documentaries has a storytelling quality to it. One of the conceits 
of cinéma vérité is that it is "vérité," but what you often find is that there are kinds of traditional narrative story processes that are involved, and that you can see within the subtext.

I do not really know much about ethnographic films. There is the enthnographic film in which we want to see ten minutes of a guy chopping with a stone ax in the forest and understand what that is. The kind of work I do, what interests me to do and what I thought was important to do was political anthropology. If anything, that is what I have done. That distinguishes my work from what certain other people do, particularly in the United States-not so much Britain. It is kind of a weird mix; the traditional anthropological venues within television do not really know what to do with my films, and the ethnographic purists do not know. Amazon Journal seems to have struck a note with people who are into this kind of postmodern perspective because of the way I talk about images.

But I am also a journalist, and I had to make a living. I would go off and do news stories too-those paid my bills. When the Amazon was the hot story of the day, I sold stories to the networks to pay for my trips to the Amazon, which was the way I could make documentaries.

Have people like the Yanomami or the Kayapó seen any of your work and how have they responded to your representations of them?

I do not really have that close of a relationship with the Kayapó. My relationship with the Kayapó was more of a news gatherer, rather than documentarian who developed contacts and relationships and approached them with the intent of establishing a working relationship.

The Yanomami have copies of all my outtakes of everything I have ever done. The Waiãpi have copies of every single image I have taken. The Waiãpi have intermediaries who work with them who are colleagues of mine in Brazil, who have a project of bringing video into the villages. So the Waiãpi have seen all of the material. The people I have worked with on those particular documentaries I have good relationships with. They are aware of what I do; I explain in great detail what I do. I know that from two spokespeople for each of these groups. Davi Yanomami and Wai Wai Waiãpi have toured and spoken with my films; we have collaborated in that process. I think that they feel comfortable, that they understood what I was doing. I do not know if the average Yanomami person is aware of the way in which those films are used. They are aware that an archive exists. And it is interesting that this archive exists in many areas which are accessible to them. And I think that the other generations might benefit from that in a way.

Are you thinking about something where they are actually doing the filming and storytelling and you are giving them technical assistance?

I would do a version of narration and translation of my film for the Yanomami. There are projects, and I have supported those projects in various ways, in which 
indigenous groups are doing those. But to be honest with you, my approach as documentarian is, if I could support those kinds of efforts and projects I would do it. But I made those films for my people. I did them in a way that I did not exploit those communities which I worked with. I feel very principled about that, and I have gotten the feedback from those communities to know that that is not the case. In this day and age, in North America, particularly North America as opposed to Western Europe, I think that it's really important that we are informed about these kinds of subjects. That is my agenda.

You said that television does not know what to do with your films. Are you targeting a general United States public with these films? In which venues are you showing your films - just in the university settings, or popular cinema?

I have been showing in art house cinemas across the country. I am on a twentycity tour sponsored by Amnesty International. I work with local nongovernmental organizations, sometimes activist groups, in every city I go to. I joke to myself that I am here to convert the converted. I learned a lot in those experiences that had to do with social movements, preconceived notions, and our own kind of rites of passage. I was interested in, without being pedagogical, sharing my own experiences with people who are interested in those experiences. And I have no problem with preaching to the converted because I think that activists are activists. These are the people who are engaged and have a commitment. I am interested in reaching other people as well. There is a lot to be learned from that period of time [late 1980s]. It is important that Amazon Journal is a film about that period of time. I have no problem with preaching to the converted.

I want to know if you everfelt that your work has been compromised, presented in a negative light or taken in a negative light?

My attitude was always that I would not mind doing even the most simplifyied news story I did during that time because I was also doing a documentary. I considered those new stories to be almost commercials for the issues that I was dealing with. There were times when the news story pushed the envelope. Not so much the stories I did because I could control those, but because of the way it was introduced, or packaged on networks, I felt a little compromised.

People have criticized one story I did about the visit of Davi Yanomami to New York at the height of the gold rush. This is the double-edged sword of media: if you work in the mainstream media, then you are going to get mainstream exposure. When you get mainstream exposure there is often a watering down and simplification of your subject matter. It was precisely that kind of watering down and simplification, distortion, that took place that interested me. As an arbitrator of images, as somebody who was a producer and cameraman who worked in a variety of venues across the spectrum, I started to become aware of this process of selection of images. Also, which images were left behind was fascinating to me. Simultaneously I was documenting people who were appropriating images. During the very volatile and intense social movement, it got 
kind of surreal in a way. But it really was not surreal, it was very real. And it was very much about the fabric of our culture. I had a lot of problems with the network news. Some people say, "Oh I am a purist" - whatever. You know what, I had to make some money. I am not good at writing grants, to be honest with you, but I know how to walk into a network place and sell a story.

I will give you an example. I had been a cameraman on a documentary about Chico Mendes. The producer was Mirandez, she was an independent documentarian. By 1988, I had been working for her as a cameraman for 60 Minutes for about two years. I spent about two weeks with Chico, four weeks before he was killed. Chico Mendes was killed on a Thursday night-walked into his back yard, two guys were waiting in the bushes. They blew him away with shotguns.

I got a call from Cultural Survival on Friday morning [telling me] that Chico had been killed. I called CBS about my great footage. I went to my contacts; they sent me to other contacts. Nobody was interested. I said, "Look, this is a story about a labor leader, an interesting guy. We have him on tape talking about the death threats against his life. We even have him on tape talking about his murderers. He names them because he was being followed. No one was interested. Marly Simmons, the Rio correspondent for the New York Times, wrote an article about Chico. It was printed Saturday morning on the front page of the New York Times. Monday morning I got calls from CBS and NBC. We ran the story Tuesday night on the CBS evening news. We ran it on Wednesday morning on CBS This Morning, and on Thursday on The Today Show. There are more stories like that. It got to the point where as a freelance journalist I started feeding my print colleagues my stories, my tips, conscientiously knowing that once their stories were printed in the newspapers I could go back with my material, which I had gotten months previously, and get my stories on the air. That is because television follows the lead of print. But there is the psychology that the world follows the New York Times.

So is it really not just an interesting story but an interest in keeping up with the other press?

I think various places legitimize news. I think that people get their ideas from the New York Times and other papers because they are not out in the field. They are not in those countries knowing what is going on. Did you know that the network bureaus closed down in the late 1980s right around the time when I was doing reporting? I was able to do reporting from Brazil because they closed their bureau nongovernmental, and they did not have anybody there. The Amazon was a hot story and their closest bureau was in Miami. The problem with news is that it is only big story reporting. We feel that we have to have a correspondent in the field in order for us to feel that we have a connection to the issue that is there. But big story reporting in television only goes to a foreign country when it is Tiananmen Square or the fall of Pol Pot. 
You are writing a journal and it"s more self-reflective than the kind of reporting you have done, and you have moved from behind the camera to in front of it. Are you at all worried about becoming the center of attention in these issues? In what ways do you feel that including yourself makes your work stronger?

There is a real danger that if you include yourself in any work you will run the fine line between being self-indulgent and self-reflective. What is the difference between self-indulgent and self-reflective? When I did Amazon Journal I actually did an hour-long version that I am not in that has a lot of interviews. One of the reasons I put myself in the film and in the book is that when I looked at the first version with my editor it was really boring. It looked like every documentary that I have ever seen about the Amazon. I knew that by the time I finished this and it was released the Amazon story as it is known in media would be done. I would have to come at it from a whole other place in order to get people's interest. I realized is that I wanted to say things, and I could not hide behind an objective narrator's voice anymore. If I was going to criticize other people I was going to have to criticize myself. I chose to do a film and a book with that in mind.

The film is a subjective documentary, it is not a personal documentary. In many ways it is a cheat because I imposed the subjective story upon it. It is not like Sherman's March, a fantastic documentary, self-reflective in an interesting way, or Roger and $\mathrm{Me}^{2}$ Michael [Moore] is a friend of mine; I was influenced by him. I was also influenced by Sherman's March.

Michael's editor is a friend of mine. She looked at a lot at copies of the Amazon Journal. We talked a lot about the voice in the film. Are you really saying what you want to say? In my career I went from being behind the camera doing objective documentaries that tried to please mainstream audiences, to stepping out and going in front of it, to doing a book. All part of learning about myself, finding my voice, feeling comfortable about saying the things I want to say. I finished the documentary before I finished the book. At first I hesitated to write the book for a long time. To be honest with you, I did not feel comfortable because I did not feel that I was much of an authority. I was not an anthropologist, I was not an Brazilianist, my Portuguese is really bad. But colleagues of mine, who are Brazilianists, who are anthropologists, convinced me. One time an anthropologist sat me down. He said, "Geoff, you have to realize that you covered some of the most critical stories during that time period. You were there, you have an archive of stuff, you should be telling the story. So go ahead and tell it." So I decided to do it and to say whatever I want.

I realized the first person storytelling process was, yes, a way for me to write. I had no trouble writing in the voice that I use in my book. I do not really consider myself to be a writer. It is just my way of expressing myself in the printed word. I was cognizant of the fact that people are interested in my life and that that was my way of bringing a reader in. I think that people are interested in a journalist and what you go through. I went to a certain extent to expose parts of 
my experiences there in a really honest way.

I was influenced by people like Spalding Gray. I got to know Spalding because I was involved in a documentary project with him. I read his work and was really interested in how he had gone from an actor to a writer, and the way he incorporated his life into a narrative. I am not saying that one narrative is any more true than any other narrative. I think that ten years from now I will look back and read this book and deconstruct it for what it was about me in that time period. I am not deceiving myself that way; it is who I am at this particular time. It does reflect the experiences that I had, but it is also a storytelling process. It has a narrative art to it. It is not like a deconstructed narrative, but it plays with ideas of deconstruction, demystification and all those other things that influenced me. I studied in France in the late 1970s. I went to my Derrida lectures, read my Roland Barthes mythologies and all those other things.

Did you ever feel like reporting or documenting was just not enough and you wanted to somehow rescue or help people or a specific individual in a more immediate way?

I talk about the photographer who took the shot of the young girl who had been sprayed with napalm in Vietnam. In that shot, she is on the roadway, running down the street. Well, he took that shot, then he pulled the car over and took the girl to the hospital. So, you can do both. As a journalist, because I was a cameraman first, I feel that your job is to get the shot. You can do both. I would never separate myself. I would never walk away from a woman with napalm, I would never walk away. Though, in Amazonia it is a little different. If you are not prepared - if you do not have the cultural cues, if you do not understand the culture - to get involved in those cultures as an outsider is a really complicated process. You do not know who you are helping, in what power structure. If you give money for medicines to somebody, you do not know who that person is. You do not know what role they play in that society. You do not know what kind of ramification that will have. So I always dealt with an intermediary source.

It may be naive, but I frankly believe in the basic journalistic principle of the power of images, the power of getting a story, and the power of getting those stories out. The Yanomami situation, particularly, was a case when the outside world saw the images of what was going on there, the outside world woke up. And I think that hundreds of lives were saved there by virtue of media exposure. So I have no problem with that.

When I was in Yanomami territory the first time, I went with gold miners, and the Yanomami did not like the fact that I had a camera and was taking images. They did not know who the hell I was or what I was doing. But I did not let that stop me entirely. At times I did, but it was for different reasons. You have to be careful. I think that there is a lot of exploitation that happens, but as a filmmaker or as a journalist you can try to work with intermediaries within those cultures and those situations. It is important, but I do stand behind that basic 
journalistic credo. The Vietnam example is a good example. Yeah, you can do both and you know most people do. Most of the people that I know do, particularly the photojournalists. There are a lot of parachute television journalists who drop in, exploit a situation, and fly out. But there are a lot of people who do both in a way. And behind the scenes what they do is give footage to places. I always gave my films to Amnesty International, Cultural Survival and all those places. I would not really let my films be used by political parties and campaigns, but for human rights groups that have established track records, I would allow the images to be used.

\section{Notes}

${ }^{1}$ O'Connor, Geoffrey. Amazon Journal (Realis Pictures Inc., 1997) and Amazon Journal: Dispatches from a Vanishing Frontier (New York: Dutton, 1997).

${ }^{2}$ McElwee, Ross. Sherman's March: A Meditation on the Possibility of Romantic Love in the South During an Era of Nuclear Weapons Proliferation (New York: Icarus Films, 1986) and Moore, Michael. Roger and Me (Burbank, Calif.: Dog Eat Dog Productions, 1989). 